fession, that it practically becomes useless for the purpose of checking epidemic disease, whilst it entails a heavy expendicure on the ratepayers, and that the Edinburgh scheme of notification strikingly exemplifies the truth of this. I am, Sir, your obedient servant, Liverpool, July 7th, 1883. ROBERT HAMLLTON.

\section{"UNCERTIFIED DEATHS IN SCOTLAND."}

\section{To the Editor of THE LANCET.}

SrR, - In the issue of ThE LANCET for June 23rd there appears an article on the above subject, in which it is stated that "regarding England we do not err far in stating that the average of uncertified deaths is about 3.3 per cent. of the total." If this calculation is correct as regards English towns, the number of uncertified deaths in this rural district must be considered enormous. In my last annual report to the Hexham Rural Sanitary Authority, a copy of which I now forward to you, it is stated that 13.6 per cent. of total deaths were not certified. At pages 16 and 44 an analysis of all uncertified deaths is given, showing that 8.1 per cent. were not certified in any way ; $4^{\circ} 0$ per cent. of total deaths were certified by the coroner, having held inquests on them and 1.3 per cent. were certified by the coroner without having held any inquests at all. It is unnecessary to add, that with the exception of those certified by the coroner after having held inquests-viz, 4.0 per cent. - the death returns professing to give the "cause of death" of the remainder are absolutely valueless. A suggestion is made in the same report, that "all uncertified deaths, whether an inquest has been held or not, should be immediately reported to the medical officer of health, to be investigated by him, instead of, as now, being reported to a non-medical coroner." Even in many of those cases on which inquests have been held no medical evidence has been given, so that these may be placed in the same category as others certified by the coroner without the assistance of an inquest. As an example of the value to be attached to such certificates I may quote a case which occurred in this district a short time ago. A death from typhoid fever having been reported in the asual weekly return I made particular inquiries regarding it. The case was that of a pupil teacher in a school in Allendale, but whose home was at Haydon-bridge, residing at the former place most of the week but returning home on Friday evenings. On Friday evening, May 25th, he walked from Allendale to Haydon-bridge, a distance of seven or eight miles, about 7 P.M. I have said, in answer to inquiries, that he was "very well." On Saturday morning he rose with a headache, and was sick, but walked about all day till half-past two, then went to bed feeling bilious and complaining of pain in his head; had his feet bathed it warm water, and had some brandy. His sister, on account of the pain in his head, remained with him till 1 A.M. on Sunday morning, when he appeared to be going to sleep; he was seen at 6 A.M. and was no worse; at half-past six he was dying. The medical attendant was sent for, but he was dead before his arrival. The above is a case regarding which the coroner (non-medical) did not see any necessity for an inquest, hut certified the death to the local registr ar as "typhoid fever," which conclusion he arrived at from what he was pleased to call "credible information." From such cases as the above, and considering the great percentages of uncertified deaths which are reported, it is obvious that some very great changes must occur before the registration of causes of death can be of any value whatever.

I am, Sir, yours truly,

J. M'Grigor MaClaGaN, M.D. Medical Offeer of Healtb, Hexham and Haltwhistle June 27th, 1883. Mural Sanitary Districts.

\section{LONG HOURS AND INSUFFICIENT FOOD.}

\section{To the Editor of THE LANCET.}

SIR,-The attention of the public has only lately been again drawn to the long hours during which railway officials are presumed to be able to work, and to the dangers to which this leads. Engine drivers and guards are, however, not the only people who daily have to perform far too many hours of incessant labour, and in London, were we to examine closely, I am sure we could find many who are being slowly killed by overwork. I was asked a few days since by a patient of mine to see her sister, who had been comrelled to leave her employers owing to severe debility. The history of the case was as follows:-A. B-_, aged about eighteen, was in perfect health nine weeks since, when she took a situation as one of the numerous assistants in a well-known retail establishment at the West-end. Her hours of work were from eight in the morning until eight at night, standing all the time, with intervale of twenty minutes for breakfast, half an hour for dinner, a few minutes for tea. The meals were badly served ; insufficient in quantity and not sufficiently varied, as the following menu will show : - Breakfast : Bread-and-butter (salt). Dinner : Hot meat and potatoes, alternating with cold meat and bread every other day; pudding twice a week, consisting of boiled rice. Tea : Bread-and-butter (salt). Supper : Bread-and-butter (salt). The food was so untempting that as a rule most of the assistants only remained in the room at dinner (?) about ten minutes, and the quantity was not sufficient. Considering this bill of fare, I did not wonder at my patient's weakness; and finding no disease sufficient to account for the symptoms, I prescribed a continued absence from her employer's premises and good food.

Fortunately, in this case there was a good home to fall back upon; but in too many instances girls have no place to go to, and dare not complain or leave tbeir places, as they know that situations, even like these, are not too easily obtained. I find on inquiry that this kind of treatment is by no means peculiar, and that in many other establishments the domestic expenses are cut down as low as possible for economical reasons. Perhaps some day a corouer's inquest may throw more light upon these matters, but, in the meantime, I certainly think that all large institutions $\mathrm{em}$ ploying female labour ought to be, like factories, under Government inspection, and not left to the tender (?) mercies of a housekeeper, whose sole idea is to keep down the weekly bills. I am, Sir, yours faithfully,
July, 1883.
A. George Bateman, M.B.

\section{"ACUTE RHEUMATISM AS A PREMONITORY SYMPTOM OF PHTHISIS."}

\section{To the Editor of THE LANCET.}

SIR, - I fail to see anything remarkable in the cases of acute rheumatism and phthisis reported by Dr. Austin in The LANCET of July 7 th. Phthisis is a very common disease, and acute rheumatism is not rare, so that we need not be surprised at the two diseases occasionally co-existing in the same individual. The more marked symptoms of phthisis would probably pass into abeyance during the attack of rheumatism, and light up again with increased severity afterwards, when the patient is left weak and exhausted. The same sort of dormancy, but for a louger period, is seen in pregnancy, also followed by a rapid development of phthisis after delivery; but it is not asserted that pregnancy is a "premonitory symptom" of consumption. If, on the other hand, as Dr. Austin seems to suggest, the joint disease was tubercular, then it was not acute rheumatism at all. I am, Sir, your obedient servant,

Harley-street, W., July $7 \mathrm{th}, 1883$. Julius Pollock.

\section{To the Editor of THE LANCET.}

Sir,-Dr. Austin in ThE LANCET of last week sketches the history of four cases of acute rheumatism as premonitory of phthisis. Without doubt, in most instances, acute rheumatism occurring in young subjects undermines the general health, so that if there be any hereditary tendency to consumption pulmonary mischief is apt to follow. Lately, I have had under treatment a lady, aged thirty-five years, who, about this time last year, had an acute attack of rheumatism, which from its duration of two months considerably reduced her strength. Most of the joints were affected ; upon subsidence of pain and swelling, cough of an irritable kind set in, and in a short time the lungs began to manifest symptoms of tubercular disease, which quickly led on to vomica; throughout the illness the tempetature remained somewhat high. At length diarrhœa set in, and the patient died of exhaustion. The father died many years since from pulmonary affection. I consider in this case the constitutional powers gave way under the prolonged 